\title{
PSYCHIC EXPERIENCE, TRUTH, AND VISUALITY IN POST-WAR VIETNAM
}

\author{
Markus Schlecker and Kirsten W. Endres
}

\begin{abstract}
During the Vietnam War, unprecedented numbers of dead soldiers were buried in unmarked graves and remain missing today. Starting in the mid-1990s, the services of psychics came into high demand, prompting the establishment of a state-approved Center for Research into Human Capabilities that continues to offer grave-finding assistance for the general public. This article discusses the cases of two well-known female psychics. As the case studies demonstrate, such research programs have established a niche for psychics on the perimeters of the official discursive nexus of truth, science, and visuality. They also highlight the variability of social and semantic processes by which different psychics are positioned in relation to recognized distinctions between legitimate and illegitimate knowledge practices and truth claims.
\end{abstract}

Keywords: human experience, paranormal, psychics, reversed agency, science, truth, Vietnam, visuality

In 2000, a report of typewritten testimony circulated among the general population in Vietnam's capital Hanoi. Titled "Search for a War Martyr's Remains: An Itinerary Full of Mysteries," it described in minute detail the arduous process of finding the remains of Trần Thị Khang, a guerrilla fighter during the war of resistance against the French, who had been captured, brutally tortured, and finally murdered in 1950. The report was written by her brother, Trần Phương, none other than Vietnam's former vice prime minister (1982-1986) and a distinguished professor of economics. In order to find his sister's remains, he had employed the help of Phan Thị Bích Hằng, a well-known psychic endowed with the special capability of communicating with the souls of the dead. After a series of encounters with Khang's soul, her burial site was located. ${ }^{1}$ Her remains were exhumed and later given a proper burial at the war martyr cemetery in her 
home place. Initially, Trần Phương had been very skeptical about the endeavor: "I was a scientist who believed only in concrete evidence. For all my life, I had never believed in souls, spirits, or ghosts." Yet by the time his sister's grave was found, his doubts had been entirely dispelled. To the scientist in him, it now seemed evident that the souls of the dead carry on an existence of sorts that, for certain people such as Hằng, is visibly and audibly perceptible. Trần Phương argued that it would not be right to negate the soul's continued existence on the simple grounds that most people do not possess that special capability ( $k h a \dot{a}$ nặng) of perception. He concluded: "If we just hastily throw everything that we don't yet know into the garbage bin of superstition, then what would be left for science to do, for science to discover?"

Beliefs in the afterlife and practices related to the care of the souls of the deceased are deeply rooted in the Vietnamese moral imagination. ${ }^{2}$ These practices often entail communication with the dead through spirit mediums and soul callers. During the heyday of state socialism in the 1960s and 1970s, they had been denied any legitimate role in building the new socialist society and were stigmatized as superstition. Beliefs in supernatural forces and the soul's continuous existence after death were to be replaced by a 'scientific spirit' that sought truth from provable facts rather than through spirit practices (Malarney 1996, 2002). By the time Trần Phương wrote his report in late 1999, however, a reverse tendency had already set in. The apparent ability of certain individuals to communicate with those who have left this world played a pivotal role in a scientific research project whose aim was to find the graves of the missing war dead. These individuals were referred to as nhà ngoai cảm, a neologism that can be translated as 'a specialist in extrasensory perception', or, to use a popular Western term, a 'psychic. ${ }^{3}$ The introduction of this new expression reflects two interrelated tendencies unleashed in the mid-1990s. First, it was indicative of a move toward thinking about spirit beliefs and practices in scientific terms that clearly departed from Marxist-materialist conceptions of such beliefs and practices as 'unscientific superstitions'. Second, it proposed a distinction between 'ngoai cảm specialists', who are able to perceive a soul's presence and interact with the dead in a dialogical manner, and spirit mediums (nguoòi nhập hồn) and soul callers (người gọi hồn), who act more or less as a direct 'channel' (or vessel) for the souls of the deceased through spirit possession. ${ }^{4}$

More than a decade after the first scientific experiments into extrasensory perception were launched in Vietnam, the number of graves that have been found through the help of both male and female psychics has multiplied by the thousands (Nguyên Bảng 2007). ${ }^{5}$ For the bereft, retrieving the mortal remains of a missing relative is of the utmost importance in order to ensure the soul's safe transition to the Otherworld and thus to avoid the illness or misfortune that could be inflicted upon them by the angry ghosts of the uncared-for dead. For the state, the sheer number of soldiers and civilians who died during the Vietnam War poses a threat to its truth claims "regarding the glory and nobility of suffering and dying for the cause” (Malarney 2001: 58). The services of psychics promise to remedy both concerns. Yet despite the apparent benefit for the common good, the state remains ambivalent about the role of these 
'experts with extrasensory perception' in determining new truths through their perception of the spirit world.

This article examines the cases of two well-known female spirit practitioners, Phan Thị Bích Hằng and Nguyễn Thị Phương, both of whom communicate with the dead, although through different methods and with different specializations. Whereas the psychic Phan Thị Bích Hằng enters into a dialogue with the souls of deceased persons and has found numerous graves through these conversations, Nguyễn Thị Phương acts as a spirit medium for the souls of the deceased, thus enabling their living relatives to engage in direct conversations with them. The two cases will be discussed in relation to an official discursive nexus of truth, science, and visuality that emerged in the 1940s and became gradually institutionalized and inculcated by way of educational campaigns, print media, and various other channels. This involved a radical insistence on the validity of scientific knowledge and the exclusion of other methods of establishing truth. We begin by investigating this discursive nexus in the socialist-revolutionary period, as well as the early đổi mói era, that is, the period of economic reforms initiated by the government in Vietnam in 1986. With the involvement of psychics in state-sponsored research programs into paranormal capabilities in the mid-1990s, the state monopoly on truth and vision started to crumble. As the two case studies demonstrate, such research programs have opened up a niche for spirit practitioners on the margins of the official discursive nexus of truth, science, and visuality. At the same time, the two cases draw attention to the variability of social and semantic processes whereby different 'ngoại cảm specialists' are situated in relation to official distinctions between legitimate and illegitimate knowledge practices and claims to truth.

We draw attention to the ways in which experiences of psychic visionsthose made by psychics and those by clients and their supporters-are condensed through accounts into a particular representational image. This image, referred to vaguely as a phenomenon, carefully situates psychic visions and the truth that they elicit on the margins of what is generally accepted-as something that is yet to be fathomed but is generally amenable to scientific inquiry. Accounts of psychic visions, as we show, frequently delegate agency away from the psychic to outside forces and foreground the public merit of their work. This approach, we argue, avoids direct challenges to the officially sanctioned view of human intentionality, which is reserved for the domains of scientific and political action.

The present study builds on insights gained in the anthropology of experience (see especially Bruner 1986; Lienhardt 1961; Turner [1982] 1996, 1986), which in turn built on Wilhelm Dilthey's hermeneutics and the pragmatism of John Dewey (see Abrahams 1986; Turner 1986). This sub-field in anthropology has problematized the relationship between experience and expression, stressing that this relation is always mediated via interpretation and performative actualizations. ${ }^{6}$ However, what we refer to as the dominant discursive nexus of truth, science, and visuality in late socialist Vietnam epitomizes the continued prevalence of positivist reductionist models of human experience, in which claims to true representations ('truth') are unambivalently made, while other 
expressions are disqualified as being simply 'false'. Our study of psychics and their supporters indicates that a more complex, dynamic, and interpretative model of human experience and its expression is gaining momentum locally (echoing findings in the anthropology of experience and its associated sub-disciplines), although it is still heavily marginalized. ${ }^{7}$ In a sense then, the anthropology of experience has been guiding us in our investigation of psychics, their supporters and critics, and the different reactions of state officials and others; it has helped us to interpret this recent trend.

\section{Scientific Socialism, Truth, and Visuality}

Vietnam's revolutionaries envisaged the task of creating a new society as inextricably tied to the struggle for national independence. Western superiority in the domains of science and technology, it was found, had been a major factor in the country's subjugation by French colonialists. The fact that the writings by Marx and Engels laid great stress on scientific procedures in exposing the hidden laws of socio-economic orders, wherein class opposition evolved, helped to interweave the anti-colonial resistance with a Marxist search for a practical concept of truth. The new Marxist ethics foregrounded "the capacity of man to use his body and mind to confront and overcome most natural and social obstacles" (Marr 1981: 131; see also Woodside 1976: 200ff.).

The vision of a new society in Vietnam required more than statements about political and socio-economic orders. It had to convey a salvational missionthe liberation from ignorance. Socialist-revolutionary ambitions to lay bare hidden laws, uncover truths, debunks myths, and replace false consciousness with emancipated knowledgeable minds deployed a scientific vocabulary ('examining', 'dissecting', etc.) that was interspersed with metaphors of visuality. It is important, we argue, to take note of the intermingling of these two themes as a public, state-driven, discursive nexus of science, truth, and visuality evolved from it. Since Vietnam's Communist Party leadership still defines itself in terms of the dominant guiding authority, its claims to a privileged access to truth have outlasted the economic reforms. What has changed is the vocabulary, which has become more technocratic and is more in line with NGO jargon. In order to grasp the current debates surrounding the paranormal in late socialist Vietnam, an understanding of this discursive nexus is important.

Statements made by Chairman Hồ Chí Minh’s chief ideologue, Trường Chinh, on Vietnam's New Culture provide a useful starting point. In his 1948 speech at the Second National Cultural Conference, Trường Chinh (1977: 224) may have appealed primarily to artists and culture cadres, yet these statements provide insight into the leadership's general understanding of the relation between science and truth: "The main aim of Marxist culture in general and of Marxist literature and art in particular is to seek truth ... It is diametrically opposed to obscurantist 'culture', the reactionary culture of the exploiting classes (bourgeois, landlords), the purpose of which is to conceal the ugly parts of society, to distort truth and to splash a coat of glamorous paint over that rotten society." 
The discursive nexus of science, truth, and visuality was obviously not peculiar to Vietnam; it has been documented for the Soviet Union and its satellite states, as well as the People's Republic of China. Yet the intertwining of education or knowledge and visuality also has a local anchoring, as is evident in terms such as 'illiteracy', which is a combination in Vietnamese of the words 'blind' (mù) and 'letters' (chĩ). Along with consolidating revolutionary visions of a new society and culture into state-socialist orders, the leadership was also faced with the challenge of making apparent the new scientific uncovering of truth, and labels helped to serve both of these purposes. For instance, the Truth Publishing House, which belonged directly to the Party Central Committee, was founded on 5 December 1945, just three months after independence from France had been declared. More importantly, as Kim Ninh (2002) has documented for pre-1965 revolutionary Vietnam, information disseminated by cultural cadres relied heavily on numerical and statistical data as evidence of this new visuality. The scientific quantification of people's social worlds as statistical facts provided a sense of an increased vision about what was really going on and was used forcefully to promote the state's vision of the new socialist society.

Along with the growing bureaucratization of Vietnam's Party State, especially after 1965, this nexus underwent two fundamental transformations in popular perception: it turned against its own citizens-aiming to extract truth from them rather than from history and socio-economic structures-and it increasingly covered up the regime's ineffectiveness and its own practices of obscurantism. In Fragments of the Present, Philip Taylor (2001: 58) writes of the Party State's “imagery of illumination," which he found in editions from the 1970s of The Youth, a daily newspaper of the Ho Chi Minh Communist Youth Organization. "The early editions of the paper were replete with references to a new 'dawn', a 'bright' new future and living 'in the light of the thought of Ho Chi Minh"” (ibid.: 56). An editor of the newspaper later spoke to Taylor in private and reflected critically on the pre-reform past. For him, state doctrine, while deploying an imagery and vocabulary of illumination that promised citizens greater visuality with regard to their social and natural world, and which was partly borrowed from Buddhist doctrines of achieving ultimate awareness, had actually blinded people (ibid.: 58f.).

Much of the anthropological literature based on research carried out in post-1986 Vietnam has drawn attention to the way in which the Party State has permitted a limited recovery of ritual practices and some innovations (see, e.g., Endres 2002; Kleinen 1999; Luong 1993, 1994; Malarney 2002). This was done on the premise that none of these practices would be allowed to make claims to uncovering additional or greater truth. Ritual practitioners and their clients were not permitted to declare that they could see more than what could be seen through the scientific modes formally acknowledged by the Party State. Officially relegated to entertainment and tourism, rituals were also viewed as providing a kind of cultural, emotional, and social reassurance of Vietnam's national essence (Endres 2002; Luong 2007). They were not to meddle in the domains of politics and science. 
Throughout the state-socialist years and continuing into the present reform era, these last two domains have been framed by the leadership as wholly governed by human intentionality. That is, both science and politics have been presented as the principal fields for human purposive action, directed at the social and natural environments of human existence so as to study carefully and intervene actively in and enhance these contexts. Thus, a major change occurred when psychics began to take part in state-sponsored research programs and when a research department for paranormal activity was formally established. What we argue in the present article is that a curious confluence is transpiring, one that involves early revolutionary ideals of scientific truth as salvation (drawing in part on Buddhist ideas of ultimate awareness) and longstanding notions of supernatural perception. Under pre-reform state socialism, the revolutionary ideals had been gradually betrayed in the eyes of the populace, while practices built around supernatural perception had been banned. The capability of psychics to see and interact with spiritual entities still remains a highly ambivalent subject for state authorities. In the current context of a market economy with a socialist orientation, these two themes of truth and vision seem to have established a niche that subtly cross-cuts the official domains of politics, science, and culture.

\section{Science and the Quest for the Paranormal}

Most people in Vietnam have no doubt that the souls of the dead carry on an existence in the Otherworld-referred to as the yin world (côi âm) -and that it is possible for certain individuals to communicate with them. ${ }^{8}$ Although there is always the possibility of fraud, countless stories of those who have encountered their dead relatives through a spirit medium attest to these capabilities and, consequently, to the existence of an afterlife. Scientific socialism did not succeed in eradicating these beliefs; rather, we may even say that it had the opposite effect. Moreover, those who firmly believe in an otherworldly existence and the ability of souls to communicate with humans have found in science a source of evidence that is consistent with their beliefs. In Vietnam, research into the paranormal started in the đổi mói era. Its onset was closely related to the issue of the missing war dead. In Gustafsson's (2009: 59) words, the Vietnam War had created for the Vietnamese a veritable population explosion in the Otherworld that not only brought painful grief to the living but also haunted them in very tangible and threatening ways. When economic conditions started to improve in the mid-1990s, the issue became even more pressing. Unable to benefit from the country's new affluence, the 'war ghosts' were increasingly felt to impede on the lives of their survivors, "if only to be noticed and, in that unsatisfactory way, remembered" (ibid.: 64). In order for the souls of the dead to rest in peace, a proper burial is of the utmost importance (Kwon 2008). The search for the bodily remains of dead soldiers thus became a prime concern for the bereaved. Besides using official services for finding traces of missing war martyrs (e.g., through radio broadcasts and, later on, television programs) or 
embarking on private search journeys (Lojkine 2005), many people also sought the help of soul callers, spirit mediums, and psychics. Much to the dismay of local authorities, individual spirit practitioners soon achieved considerable fame for their apparent success in finding the skeletal remains of the missing in unmarked burial sites or in nameless graves at war cemeteries. Some of these searches, however, were conducted under the official supervision of provincial People's Committees. ${ }^{9}$

When the Vietnamese government started cooperating with the United States in order to investigate the unresolved fate of about 1,500 American servicemen reported as missing in action, the issue of Vietnam's own 300,000 missing soldiers grew in urgency (Mydans 1999; Pomonti 2000). In order to legitimize the tremendous loss of life during the war, the Party State had already put much effort into the commemorative project of glorifying the dead soldiers' supreme sacrifice for the national cause of independence and reunification (Malarney 2001). This, however, had not tackled the menace posed to the legitimacy of the Party State's monopoly on power by the ability of the war ghosts "to relate to pressing moral and political issues in contemporary life" (Kwon 2008: 18). The special capabilities of the 'psychics', as they were soon referred to in the media (initially in quotation marks), were seen as potentially useful in resolving this issue. At the same time, it was felt that this had to happen in a controlled, supervised way-one of "scientific research into extrasensory psychic abilities” (Xuân Nguyên 1997: 1; see also Nguyễn Viêt Chiến 1997).

In the mid-1990s, different research groups began to investigate the various methods used by psychics in order to trace the missing dead. One scientific project was set up by the Science and Technology Union for Applied Informatics (UIA), ${ }^{10}$ in joint cooperation with the Institute for Criminal Sciences of the Ministry of Public Security and the Research Center for Supporting Traditional Culture and Technology, a member of the Vietnamese Association of Historical Sciences. UIA began by conducting a 'scientific experiment' into the finding of graves 'by special capabilities', which tested the success rate of several well-known psychics and carefully documented each case. The second investigative unit, the Center for Investigation into Human Capabilities (CIHC), was established within the precincts of the Institute of Physics. Like the UIA-based research venture, it was funded through the Vietnam Union of Science and Technology Associations (VUSTA), a national non-governmental organization of Vietnamese intellectuals who specialize in different fields of science and technology. ${ }^{11}$ CIHC's mission was to discover people with unusual abilities, to test and verify these capabilities, and to establish hypotheses to explain them (Ngọc Huyền 2006). As with UIA, CIHC enrolled a number of renowned psychics to conduct searches for missing corpses and to identify graves under the supervision of the center. ${ }^{12}$ With funding from the Ministry of Science and Technology, as well as from VUSTA, several projects related to finding the graves of missing war martyrs were conducted. Whereas earlier programs investigated the different ways in which psychics communicate with the dead in order to find the remains of deceased persons whose names were known to the psychics, subsequent research turned to the psychic capability of 
identifying the names of war martyrs whose remains rested in unnamed graves at various provincial and national war cemeteries. This 'reversed searching' endeavor is particularly interesting because it ascribes agency to the deadthat is, their ability to identify themselves to the psychics-and thus implicitly acknowledges the existence of an afterlife. This was referred to as the phenomenon of 'war martyrs finding family members'.

Over the years, several thousand cases were solved, although the numbers vary in different accounts. Few had so far been verified by DNA testing, mostly due to the lack of financial means of the bereaved. Nonetheless, both institutes put their overall success rate at 70-80 percent. Despite this favorable rating, the government apparently discourages people from seeking the services of psychics who operate outside the supervision of the two institutions. In an interview with a Ho Chi Minh City newspaper, Vũ Thế Khanh, the director of UIA and the founder/head of the research group on the paranormal, maintains that 90 percent of the self-proclaimed psychics in Vietnam are either "nonsensical" or "fraudulent cheaters."13 Quite often, these concerns seem justified. Fortune tellers, ritual specialists (thầy cúng), and soul callers have been charged with 'trading in spirits' (buôn thần bán thánh) throughout Vietnam’s turbulent history, and the media delight in exposing scandalous cases of huge financial losses caused by charlatans and impostors (see, e.g., Đào Nguyên Lan 2007; Tùng Đệ 1997). ${ }^{14}$ In the precarious case of the missing war dead, therefore, the state obviously wants to stay in control. Yet, as Vũ Thế Khanh admits, the demand is much higher than the capacity of the research units. In 2007, only 10 licensed psychics operated under the umbrella of his institute, and UIA had far more search requests than it could handle. The same is true for CIHC. One of the most successful and well-known psychics affiliated with the center is Phan Thị Bích Hằng, a 40-year-old native of Khánh Hòa village in the Northern Vietnamese province of Ninh Bình.

\section{Latent Capabilities: The Case of Phan Thị Bích Hằng}

The psychic Phan Thị Bích Hằng has attracted considerable media attention. ${ }^{15}$ A simple search for her name on the Internet yields over a million pages. Video and audio recordings-in which she gives an account of her extrasensory perception or is followed by a film crew who document her conversing with the dead-are widely available in shops and on the Internet. Part of the reason for this prominence is Hằng's own wish to generate a greater acceptance of psychics in Vietnamese society as neither tricksters nor spirit-possessed mediums.

Hằng, then 26 years old, began to participate in the work of $\mathrm{CIHC}$ in Hanoi in 1997, using her special skills to assist in the search for the missing corpses of soldiers and the identification of anonymous war martyr graves. She is said to be the only psychic who requires a photograph of the deceased in order to establish contact and communicate with the dead person. Many of her colleagues draw maps (using information given by the deceased's spirit), which then guide family members or researchers to the burial site. Hằng instead 
travels to the sites herself, along with her clients. Her method thus does not quite correspond to the widely used description of 'finding graves from afar'. ${ }^{16}$ Unlike other psychics, such as the state-certified male psychic Nguyễn Văn Liên (see Schlecker n.d.), who can only see the dead and follow them mentally/ spiritually across the land to their graves, Hằng can directly converse with the dead. Comparable to an overheard telephone conversation, clients and spectators hear Hằng speaking to another person, taking turns in the conversation. In this manner, Hằng establishes the exact location of the grave. In 2007, Hằng, together with nine other psychics, received the Huyền Thông A 15,000 Award, with 15,000 indicating the number of war martyrs that the group of psychics had helped to discover between 1997 and 2007 as part of the research program carried out by CIHC (Nguyên Bảng 2007).

A speech that Hằng gave in 2004 at the southern branch of $\mathrm{CIHC}$ in Ho Chi Minh City provides a good overview of her background and activities. Typical of many psychics, Hằng went through a near-death experience, after which she gradually came to realize her special abilities. ${ }^{17}$ Hằng devotes a good part of her speech to the predicament that she and her family were placed in as she became conscious of her psychic abilities and began to deploy them in her local community. When her psychic skills began to attract large numbers of clients from outside her local community, neighbors and other villagers grew concerned. As a result, her family was reported to the local authorities. Hằng approached several higher-ranking cadres of the Party and asked to assume full responsibility. The cadres decided on a solution that would both benefit the local community and improve her and her family's reputation. She was asked to use her special skills to "do something good for your home place, so that everyone can acknowledge your gift.” Wisely, Hằng also enrolled representatives from state and academic institutions, notably from the Ministry of Culture and the Institute for Sport Sciences, whose testimonies later helped to establish the genuineness of her psychic abilities.

What we would like to draw attention to is the close link in discussions about psychics between the question of their genuineness and that of their public merit, that is, their willingness to help others, especially those outside of their family. Genuineness is thus not tied exclusively to scientific facticity, which CIHC's research program has tended to foreground. In general, spiritual practitioners are accused of fraud more often when they are suspected of personal profit making. We see these attitudes reflected in the case of Hằng: the popular perception of her genuineness as a psychic evolved along with the degree to which she rendered help to people and groups outside of her own family. ${ }^{18}$

The link between merit and genuineness clearly plays a significant role with regard to Hằng dressing in Buddhist garb at recent appearances and her attendance at Buddhist ceremonies and conferences that have been organized by pagodas and institutions belonging to the only state-endorsed Vietnamese National Buddhist Sangha (Giáo Hội Phật Giáo Việt Nam).${ }^{19}$ One can notice that Hằng has more explicitly aligned her work as a psychic with formal Buddhists concepts of suffering souls and their salvation. In an interview conducted in 2007 on the occasion of a Buddhist ceremony held for the salvation of suffering 
spirits in Lâm Đồng province, ${ }^{20}$ she affirmed her closeness to Buddhist concepts: "My family follows Confucianism. My father is a military officer, my mother a teacher. Since I discovered my capabilities to see, listen, and speak to people from the Otherworld [nguoòi cõi âm], and inspired by their guidance and advice, I have had many opportunities to follow Buddhism ... If you could only see hear and see all the spirits that congregate here today like we can ... I really believe in the salvation of souls [sụ siêu độ của nhà Phật]."

At the outset of her 2004 speech, Hằng describes the first manifestation of her special psychic skills as "not an illusion, but a fact." She goes on to describe her relatives' and fellow villagers' reactions as shifting from plain disbelief or suspicions of "a delirious mental disorder" to an understanding that the spiritual realm had bestowed a divine gift (lộc) on her. Hằng does not resolve this, but from then on she refers to her psychic skills as a "phenomenon" (hiện tuoong). The use of the term 'phenomenon' is one of her most vital rhetorical devices, as it allows her to avoid linking science explicitly with supernatural perception or paranormal abilities. This phenomenon, her listeners are told, has an "essence" (bản chất) and a "structure" (co' chế)-that is, it can be shown to actually exist. But it continues to be a "large question" that equally baffles "many countries" in other parts of the world. The implicit reference is to Western countries, which have set scientific standards, thereby furnishing this phenomenon with legitimacy.

In the account of her first experiences of psychic capabilities, her father constitutes her most important critic and is the person whom she is the most intent on persuading of the facticity of her abilities. Described by Hằng as scientifically minded, her father personifies the legitimate, male form of knowledge and, of all the people around her, remains skeptical of her abilities for the longest period of time. A military officer and Party member, he underwent a trial by nearly being disciplined for his daughter's allegedly superstitious activities. It is highly important to note that Hằng then chose the university entry examination as a way to persuade her father that she was mentally sane and not prone to illegitimate kinds of beliefs. Having successfully passed the examination, Hằng then studied at Hanoi's National Economics University and graduated in the late 1990s. Her accomplishments in this domain of social science clearly helped to add legitimacy to Hằng's person and psychic activities, and she successfully cultivated and expanded this relation by completing a degree, by involving researchers in her work, and finally by taking up a permanent job within an academic institution. Today, Hằng works as an administrative staff member at the Hanoi University of Business and Technology. Notwithstanding all this, what remains is that her skills are a phenomenon, one that is unfathomable yet evidently effective. The term 'phenomenon' as a rhetorical device thus situates psychic and other paranormal skills on the margins of the discursive nexus of science, truth, and visuality, positioning them as neither illegitimate means that generate pseudo-knowledge nor as explicitly scientific ones.

The twofold sense of visuality that is brought into play by research into psychic abilities is highly insightful. On the one hand, psychics such as Hằng 
are often said to 'see' more than average human beings. Villagers in Hải Phòng province described psychics as having a "gaze that could penetrate the entrails of the earth" (nhìn thấu lòng đất), obviously referring to the underworld of the dead (cf. Schlecker n.d.). On the other hand, the use of the term 'phenomenon' lays stress on the lack of clarity when it comes to research into psychic abilities. What is implied is a sense that psychics themselves cannot really account for their special skills. Unlike scientists, they do not follow specific procedures. The whole scientific principle of making experiments reproducible is absent here. Instead, the process involves spontaneous conversations that unfold in varied ways.

This brings us to the second point, that of the psychics' agency. What we wish to highlight here is a conception of 'reversed agency', that is, the way in which the revelation of Hằng's initially latent skills and the subsequent growth of her capabilities were triggered by the actions of the dead. It is highly important to take note of a significant parallel development: as Hằng's psychic senses progressed, culminating in her ability to communicate freely with the dead, agency shifted toward the dead. Hằng herself noted that initially she had to visit a site to establish contact with a dead person. Gradually, however, the dead would approach her and "knock her on the head" (gõ đầu) to get her attention. Information about her special gift was circulated among the dead, and soon the number of requests she received from the dead grew out of proportion. Hằng had to withdraw at times to protect her health. Contact with the yin qualities from the sphere of the dead is said to diminish a person's life forces.

The rhetorical emphasis placed on reversed agency-that is, an agency vested in the dead who then trigger or prompt the psychic and clients to act-is important in avoiding challenges to the established knowledge order. In their accounts, Hằng and other psychics tend to forgo assertions involving the ability to initiate actions directed at dead persons. This would imply claims to a central place within domains that are reserved principally for the concept of human intentionality, such as science or even politics. In conjunction with Hằng's first rhetorical device-the term 'phenomenon'-human agency is replaced in her account by a diffuse non-human agency, that of the dead catching her attention and urging her to take actions for them.

Whereas successful psychics like Hằng, who help to discover the bones of fallen soldiers and identify anonymous graves, have gained in official acceptance through the scientific research programs of CIHC, spirit mediums and soul callers, who invite the souls of the dead to possess their own or another person's body temporarily, appear to fall into a category of spirit practitioners who pose a more potent threat to the official knowledge order. ${ }^{21}$ Therefore, initially, they were not subject to scientific investigation. An exception occurred in the following case of the famous spirit medium Nguyễn Thị Phương. The concerted efforts of some of her scientifically minded supporters to prove her genuineness and the merits of her services not only had a positive effect on her relationship with the authorities in her commune, but were also the likely trigger for the recent expansion of research beyond psychic grave finding to possession by the souls of the dead. 


\section{Joyful Encounters with the Dead: The Case of Nguyễn Thị Phương}

Nguyễn Thị Phương is a female spirit medium who, over the past decade, has acquired considerable fame throughout Vietnam for her 'special ability' ( $k h a ̉$ năng đặc biệt) of channeling the dead and for the accuracy of her séances. Among her clients are reputable professors and high-ranking government officials. She lives in Thanh Hóa province, an approximately three-hour ride from Hanoi. Conveniently located near the highway, her house has a spacious yard, a row of service rooms, a waiting area for clients, and a small shrine that faces the entrance of her reception room. Clients respectfully address her as Cô, which is a kinship term ('younger paternal aunt') and a polite form of address for young women. Born in 1974, Phương specializes in hosting the souls of the dead during possession séances, and this is what most people who seek her services come for: to converse with their ancestors and relatives in the Otherworld in order to obtain clarification, advice, and consolation on all sorts of family-related and personal matters.

Before seeking her services, clients prepare for the event by praying at their ancestral altar or by visiting the graves of deceased family members and urging their souls to accompany them. When clients arrive at Phương's compound, they usually place some offerings (fruit, incense, rice cakes, votive paper money) on a plate and silently say a prayer, invoking the deceased person they would like to establish contact with. ${ }^{22}$ The clients then linger in the waiting area until their relative's soul manifests itself in Phương and calls out the client's name. This, however, may take up to several days or even weeks, as it is allegedly not up to Phương to decide when a particular soul will enter her body. Moreover, Phương receives souls only during her 'yin business hours' (giờ làm việc âm), and the number of clients is usually much larger than the number of souls she can accommodate during that time. Thus, clients often spend several days at the compound; those who can afford it may spend the nights in the neighboring four-story guest house run by her in-laws (see Bùi Duy Tâm 2010).

When during the 1990s her fame spread across the region and more and more clients started visiting her house, commune officials became concerned with maintaining order and security and started impeding her work. Her supporters in Hanoi, however, included influential scientists who brought Phương's case to the attention of CIHC. Therefore, in April 1999, CIHC drew together a small group of researchers in order to conduct a project aimed at investigating Phương's special ability. ${ }^{23}$ From the sympathetic nature of the report, it is apparent that the project had been intent on finding evidence that would justify the spirit medium's fame and judge her capability of 'calling the souls' (khả năng gọi vong) to be on an equal plane with that of 'officially recognized' psychics, such as Nguyễn Văn Liên and Phan Thị Bích Hằng.

The research was carried out in January 2000. Altogether, 97 clients were interviewed, of whom over 30 percent had a university education and 48 percent were cadres and public service personnel. All of the cases carefully documented the clients' purpose, the souls that had spoken through Phương, the issues that had been addressed during the conversation between the clients and 
the souls, and the clients' level of satisfaction after the session. The report states that clients felt that their encounters with the souls of the dead had been effective in solving a variety of personal matters and in 'clearing the psyche' (giai tóa tâm lý) of burdens and tensions. With very few exceptions, the interviewees felt joyful (vui) after Phương had channeled their loved one's soul, and most returned to their homes "with a smile on their lips and tears in their eyes."

After a brief description of her place, Phương is characterized as a devout Buddhist who starts each of her sessions with a prayer to Buddha. As in Phan Thị Bích Hằng's case, the effort to make explicit the spirit medium's affiliation with Buddhism serves a legitimizing purpose. The researchers then proceed by listing a number of reasons why the soul caller's spiritual work should be considered 'genuine' rather than superstitious or fraudulent. Proof of her authenticity is found primarily in the fact that it is actually not Phương who calls the souls to possess her. Rather, it is the souls who take agency and, after having followed their relatives to Phương's shrine, manifest themselves in the young woman. Phương's special capabilities, so the report states, must therefore not be confused with some kind of telepathic mind-reading ability that extracts the information directly from the clients. Here, again, the apparent agency of the souls is seen both as 'scientific' proof of an afterlife existence and as evidence of the medium's genuineness. Further confirmation was seen to have emerged during situations when a soul would possess Phương and call out the name of a client. Often, more than one person of the same name would be present in the waiting area, and in this case the soul would always be able to provide further details that ruled out other persons in the waiting hall. Moreover, the souls channeled by Phương often talked about many things that had long been forgotten in the families concerned or that were verified upon the client's return home. Many reports of clients posted to various blogs and forums on the Internet confirm this claim. For many skeptics who went to see Phương, their encounters with the dead dispersed all their doubts about an otherworldly state of existence after death, which had been made perceptible by the medium. ${ }^{24}$ In the conclusion of their report, the researchers state that all clients basically arrive at the understanding that "[t]he Otherworld is true/real [có thạt ]; it is an objective truth/reality that has to be researched by scientists."

Besides providing some general findings about the souls of the dead, the report maintains that souls always give morally sound advice to the living, such as to refrain from burning too much votive paper money (which the state regards as wasteful) or from being too superstitious, to obey the law, and to seek the help of a medical doctor in case a relative is struck by a 'worldly' illness. Again, there is a legitimizing tone to these statements, in that the dead are characterized as rational agents who act within the state's regulations instead of being subversive of hegemonic authority. Even more importantly, however, the report stresses the therapeutic value of the encounters. The souls' attitude toward the living is described as fundamentally empathic and supportive. Their conversations with the souls of the dead thus instilled in Phưong's clients the certainty that the dead never cease to care for and take care of the living. The chief value of these encounters, the researchers assert, resides in their capacity 
to resolve many personal problems and family issues in the world of the living, thus making the clients' lives "more honest and humane." The researchers conclude that, by helping countless people from all walks of life in so many ways, Phương makes a positive contribution to society that deserves praise and should be acknowledged.

The report on Nguyễn Thị Phương illustrates that research into human capabilities in contemporary Vietnam very much concentrates on the effects produced by the psychic abilities of certain individuals-that is, on what these abilities bring about rather than on how these effects are brought about. In the BBC documentary Psychic Vietnam (Phua 2006), Nguyễn Chu Phác, then head of the parapsychological section at CIHC, puts it simply: "I call it "practical science'-those who experience it will believe it!" 'Truth' is thus derived not from reason but from the experience of the spiritual world. Phương's ability to make 'perceptible' to her clients the world of souls and spirits (linh hồn) is viewed as substantive evidence of its true (or real) existence.

Furthermore, we argue, truth is established on rather pragmatic grounds in the sense of William James ([1907] 1981: 37), who sees truth as a species of good and not as a category distinct from good: "The true is the name of whatever proves itself to be good in the way of belief, and good, too, for definite, assignable reasons." In the case of Phương, this 'good' is, first and foremost, the public merit (công) of her abilities. However, unlike in the case of statecertified psychics who, first and foremost, devote their special capabilities to the task of locating the graves of missing soldiers, the 'public merit' of soul callers such as Phương (and other spirit practitioners who act as a principal channel between the dead and the living) has yet to receive the same degree of unofficial toleration or acceptance as psychics. To a good extent, this has to do with a legacy of possession cults and related practices that had been 'disclosed' by state authorities as fraudulent trickery perpetrated by shady businesses. Research into encounters with the Otherworld by UIA scientists was not limited to psychics but included a wide range of subject matters. ${ }^{25}$ Among them were also possessions by the souls of the deceased (nhập hồn), as well as the ability to call upon the souls (gọi hồn) and invite them to possess another human being. What needs to be stressed, however, is that while initially all research was conducted in secret, the investigations into psychic abilities were apparently considered less problematic. Information about these studies was thus allowed to be released to the public earlier, whereas that on more sensitive subject matters was withheld until very recently. Articles such as that cited above by Tin Tức Online are evidence of a gradual widening of the domain of semi-legitimate paranormal activities and an indication of increasing research in this field.

\section{Conclusion}

What we have examined in this article is a fascinating process that has brought together unlikely allies and has had unanticipated consequences-outcomes that were not always welcomed by the authorities. Aware of the widespread 
discontent with the issue of unburied soldiers and anonymous graves (cf. Trần Ngọc Lân 2007: 5), Hanoi's state departments had, in the 1990s, set up the research programs described above, which involved academics, cadres, and psychics. This lent an aura of legitimacy to psychics and paved the way for a more general acceptance of their skills, even among staunch supporters of state-socialist secularization. ${ }^{26}$ This rapprochement has also, more recently, begun to clear ideological obstacles for comparable research into the skills of spirit mediums. Unlike psychics, mediums pose a greater challenge in this regard. The government's effort to develop an explanation for mediums that can harmonize with its own purposes, similar to that formulated in favor of psychics, is more difficult.

Official engagements with psychics through state-sponsored research programs provide valuable insights into the ideological transformations and contradictions that have ensued, along with the đổi mót reforms, since the mid-1980s. The challenges to the epistemological and socio-political orders are evident. The public recognition of psychics may open up a Pandora's box, potentially giving legitimacy to beliefs in the afterlife and spiritual forces. In that such forces affect human intentionality, they suggest limitations on the part of the leadership to administer to society and to regulate its various domains of action. The phenomenon of psychic abilities could still be accounted for in terms of natural human faculties that are simply more developed in certain individuals. With spirit mediums, the existence of independently acting supernatural entities is more pronounced.

By examining psychics and their involvement in research programs that are primarily geared toward the search for war martyrs, we have highlighted an intersection of a number of themes that pertain to human experience and its expression with regard to questions of truth. First, state authorities, especially at the local level, face a problematic legacy of four decades of pre-reform 'highmodernist' socialism (cf. Scott 1998), which involved a radical insistence on the validity of scientific knowledge and purges of alternative truth regimes. It necessitated a firm stance on human intentionality, that is, the ability to investigate, order, and explain, in principle, all social and natural phenomena. The careful phrasing of psychic powers as unfathomable phenomena and the failure of Nguyễn Thị Phương to be recognized as a benefactor to the general public are in no small way the result of this legacy. Unlike Phan Thị Bích Hằng and several other state-certified psychics, such as Nguyễn Văn Liên, Nguyễn Thị Nguyện, and Nguyễn Ngọc Hoài, Phương and the issue of spirit possession occupy a position closer to the more controversial end of a spectrum of supernatural perception, of which psychic abilities are at the other, least problematic end.

Secondly, implicit in the debates and statements surrounding the work of psychics is a conception of truth that cannot be fully accommodated by the discursive nexus of science, truth, and visuality. What we have highlighted is a notion of truth that can be framed in terms of a genuineness that is inextricably tied to questions of public merit. A person of distinction (nhà) is recognized as truthful if he or she has successfully given evidence of a willingness and ability to render meritorious service to the wider community. That community may 
be the whole nation, as in the case of the grave-searching research programs, but it can also refer to a local village that has benefited from the discovery of an ancient vestige.

Efforts on the part of state representatives and scientists to cast psychic techniques as scientific tend to shift, frequently and subtly, to a discussion of merit and genuineness. What we have here are indications of an emergent alternative model of human experience and its expression that takes note of the complexity, dynamism, and interpretation that are involved in this relationship. Thus, in the case of failure, a psychic may still be acknowledged as providing access to truth, given that his or her actions are recognized as genuine efforts to serve the community. This sense of truth is an opportunity for psychics and their sponsors to negotiate a position within the discursive nexus of science, truth, and visuality. It is at the same time a challenge to state-sponsored conceptions of a scientifically validated truth. The continuities between the work of statecertified psychics, on the one hand, and those who operate outside of scientific and state supervision, on the other, force representatives from the domains of science and politics to establish a borderline between a minority of legitimate psychics $^{27}$ and a majority of fraudulent tricksters. The more recent inclusion of spirit mediums in research programs signals that a somewhat less exclusive line is being drawn.

Alexander Woodside (1997: 66-67) wrote of a "quasi-millenarian political consciousness" that had pervaded the early revolutionary vision of a new society in Vietnam. It conjoined a faith in modern science with long-standing local ideas of spiritually efficacious persons endowed with sacred powers. What emerges from the present study is that a very similar conjunction seems to be at play in accounts of and research on psychics. Both modern science and efficacious persons have in common a privileged vision, an insight into processes, entities, and forces that are not normally perceptible to the human eye. Unlike scientists, however, persons with special capabilities are generally thought to meditate or channel these powers rather than initiate them in the sense of methods. This clearly builds a tension that centers on the question of human intentionality and continues to pervade the recent state-sponsored research conducted on psychic abilities.

Precisely for this reason, psychics and those sponsoring them walk a tightrope in their efforts to attain official recognition. They have to negotiate between the domain of science, which is exclusively reserved for human intentionality, and conceptions of spiritually efficacious persons as mediators of mysterious, non-human powers. What we have referred to as reversed agency designates rhetorical strategies in accounts of psychics. Reversed agency means that psychic perception is presented as an interactive process, often triggered and partly guided by external forces. Psychic perception is thus rendered distinct from scientific inquiry. Reversed agency locates intentionality neither within psychic specialists nor wholly outside of them. By delegating agency, in part, to forces outside of them, psychics steer clear of the domains officially reserved exclusively for human intentionality, especially science. At the same time, psychics also insist on their share of agency. Psychic skills are often acquired through a near-death 
experience whereby the psychic acquires sensitivity toward the yin qualities of the world of the dead. This sensitivity can then be developed, but it may also subsequently decrease. Psychics actively gather specific information for clients and later test its validity either in person or through clients. Thus, there are elements in the procedures of psychics that are comparable to scientific inquiry.

Endeavors to establish a niche for psychics on the margins of the official discursive nexus of truth, science, and visuality, which is itself changing, may successfully exploit the current ideological transition. Yet these efforts continue to be looked on ambivalently by authorities at the national and regional levels. Vietnam's present leadership is increasingly toning down its state-socialist rhetoric, but it also hesitates to give much room to the socio-political 'by-products' of a market economy, most notably civil rights. The failure of Nguyễn Thị Phương to have her social merits recognized and the transformation of Phan Thị Bích Hằng into a national benefactor illustrate the contingent social and semantic processes whereby the place of individual psychics within this nexus is established.

Markus Schlecker is an Affiliated Researcher at the Max Planck Institute for Social Anthropology, Halle/Saale. He has conducted research in Northern Vietnam since 1998 and has focused on Vietnamese imaginations of the social in the reform era. His research interests include state socialism, modernity, ideas of relatedness, and contextualism in the human sciences. He is completing a monograph on the role of bones and burial practices in contemporary Vietnam and a co-edited volume on ethnographic studies of social support.

Kirsten W. Endres is a Senior Research Fellow and Head of Research Group at Department II, Max Planck Institute for Social Anthropology, Halle/Saale. She has conducted research in Northern Vietnam since 1996, focusing on the dynamics of religious and ritual change since its economic reforms. Her forthcoming monograph, Performing the Divine: Mediums, Markets, and Modernity in Urban Vietnam (2011), examines the flourishing of urban spirit mediumship as part of the recent revival of popular religion in Vietnam.

\section{Notes}

1. In these encounters, Phan Thị Bích Hằng did not transmit Khang’s words in a direct manner. Rather, she communicated with the soul by posing questions out loud and receiving answers that were 'audible' only to herself. She then reported what the soul had told her.

2. For more on attitudes toward death and the afterlife, see Endres (2008), Jellema (2005, 2007), Kwon (2006, 2008), Malarney (2001), Phan (1993), and Schlecker (n.d.).

3. Merriam-Webster Online gives the following definition for the word 'psychic' (as an adjective): "sensitive to nonphysical or supernatural forces and influences; marked by extraordinary or mysterious sensitivity, perception, or understanding" (http://www. merriam-webster.com/dictionary/psychic). This accords with the Vietnamese explanation 
for ngoại cảm as given on Wikipedia: "Ngoại cảm is a special human ability. People who have the ngoai cám ability do not use their normal senses. It is the ability to feel/experience through a sixth sense, such as the ability to talk with the dead, the ability to monitor other people, to foretell the future, to know about the past, etc." (http://vi.wikipedia. org/wiki/Ngoại_cảm; accessed 16 June 2010).

4. Soul callers channel family ancestors in order to receive information about their wellbeing in the Otherworld and/or to obtain advice on general family matters. Spirit mediums ritually embody other 'spirits and saints' (thần thánh), for example, deified heroes or the deities of the Four Palaces (Tứ Phủ) (see Endres 2011; Fjelstad and Nguyen 2006). The latter especially pose the risk of meddling in the Party State's commemoration of war heroes (de Tréglodé 2001) and state-approved national heroes (Pelley 2002; Pham Quynh Phuong 2009).

5. The authors of this article did not conduct fieldwork focused on the work of psychics, although both came across psychics and accounts of their work during multiple and extensive fieldwork projects. Most of the material discussed here therefore derives from textual sources (printed materials from both state departments and the mass media or electronic media obtained over the Internet) and video recordings. While two female psychics were chosen as case studies for this article, there are numerous male psychics as well, for example, Nguyễn Văn Liên, possibly the most famous psychic who is also government-approved.

6. This sub-field developed alongside the work of Jacques Derrida. See, for example, Derrida ([1974] 1998).

7. With regard to related sub-disciplines, for the anthropology of performance, see, for example, Bauman and Briggs (1990); for the anthropology of emotions, see Rosaldo (1984).

8. The Vietnamese concept of the soul is complex and distinguishes between the spiritual soul (hồn) and the material soul (vía or phách), which consists of nine elements for females and seven for males. These elements are biologically embodied and closely tied to a person's sense organs (see Kwon 2008: 105-106; Phan 1993). After death, it is the hồn that communicates with the living.

9. In 1992-1993, for example, the People's Committee of Ninh Bình supervised the psychic grave finding of 13 war martyrs at Non Nước Mountain (see Nguyễn Chu Phác 2000; Thu Hằng 2005).

10. The Vietnamese title, Liên Hiệp Khoa Học Công Nghệ và Tin Học Úng Dụng, is officially translated into English as Science Technology Union for Informatics Application (see http:// uia.edu.vn/). An article from the Web site Thư Viện Pháp Luật reported on 6 April 2009 that even though the government had "not approved funding" research into the paranormal, it had "given permission" to several scientists to set up "a separate department" to "secretly investigate" these phenomena (see http://www.thuvienphapluat.vn/?CT = NW\&NID =29587). Documentation of these proceedings can be found in UIA (n.d.).

11. For more on VUSTA, which was established in 1983, see http://pages.cs.wisc.edu/ vu/ vnsa/1997/vnsa20/msg00168.html. UIA also belongs to VUSTA.

12. Reports on the results of the first round of experiments were published in 1997-1998 in the journal Thế Giói Trong Ta (issues 51, 54, 58, and 59).

13. "Ông Vũ Thế Khanh, Tổng Giám đốc Liên hiệp KHCN tin học ứng dụng UIA: Hơn $90 \%$ nhà ngoại cảm là 'rởm'” [Mr. Vũ Thế Khanh, Director of UIA: More Than 90 Percent of Psychics Are 'Nonsensical'], Xa Lộ Tin Tức Online, 31 October, http://www.vusta.vn/ Temps/Home/template2/?nid = 4EA3 (accessed 16 March 2011).

14. See also "Những trò lừa bịp mới thông qua dịch vụ 'tìm mộ liệt sĩ”" [New Fraudulent Tricks Used by Martyr Grave-Finding Services], An Ninh Thé Giói, no. 206 (7 December 2000), 1, 5 .

15. Information about the psychic Phan Thị Bích Hằng comes from a range of sources, including the proceedings documented by UIA (n.d.), the volume by Trần Ngọc Lân (2007), several videos and DVDs, a transcript of her 2004 speech, and a large number of Internet forum discussions and Vietnamese online media articles. 
16. Clients of other psychics, once they have arrived at the site, often have to make repeated phone calls to the psychic to fine-tune the instructions. Not infrequently, information about place names and landmarks indicated on the map have changed or have been removed.

17. At the age of 17 in 1988, Hằng had contracted rabies from an infected dog in her natal village and failed to treat the illness in time. Some time later, she fainted and the same evening stopped breathing. Following custom, which deems the death of a child to be a very inauspicious event, deceased children are shrouded and buried quickly. An older relative, however, insisted that Hằng's family should wait and should not cover her face with a handkerchief or perform prayers with incense sticks. The next morning, believing that she had died, her father, a military officer, fired several volleys of honor, as he had promised her previously, the noise of which brought her back to full consciousness. Hằng mentions in this context that when former Party General Secretary Lê Duẩn had died in 1988, seven volleys had been fired in his honor. Hằng then fully recovered, although her parents remained worried about possible relapses and a permanent mental disorder.

18. Of great merit to Hằng's natal village was her discovery of an ancient grave of a general of the Trần dynasty-a finding that was later certified by the district's Culture Department. Members of the Trần court had taken refuge from the army of the Champa kingdom in what was now Hằng's village. A vast field had been used for their royal tombs, which in present times had served as a football field. On another occasion, Hằng conversed with dead villagers who had lived 700 years earlier and who guided her to the remains of an ancient pagoda in her village. Cadres from the Ministry of Culture were able to unearth the ruins and finally bestowed the title 'historical vestige' on the pagoda. These discoveries brought fame and state recognition to the local community-attention that was greatly desired, especially in the rural hinterland.

19. Although it had been recognized as a state-approved mass organization in the pre-reform era, since the late 1980s Buddhism has been increasingly delineated as a legitimate religious institution, in contrast to an expanding field of unofficial spiritual practices.

20. Altogether, seven psychics attended the Trai Dàn Chẩn Tế Bạt Độ ceremony.

21. The political potential of spirit possession, as both a form of political contestation and a way to power, has been well-documented and theorized in anthropological research (e.g., see Bubandt 2009; Kapferer 1997; Lewis [1971] 1989; Sharp 1993; Stoller 1995).

22. Some clients place a small sheet of paper that contains their name and their requests together with their offerings. However, skeptics and critics argue that the soul caller may know the ancestor's name through these sheets rather than through 'real' possession. See, for example, "Bí mật trong những cuộc gọi hồn: Gọi hồn ... chời ơi!” [The Secrets of Soul-Calling Séances: Soul-Calling ... for Heaven’s Sake!], Thư Viện Pháp Luật Online, 28 September 2009, http://www.thuvienphapluat.vn/default.aspx?CT = NW\&NID = 30226.

23. The project was initiated and partly funded by Ngô Kiều Oanh, a scientist at the Vietnamese Academy of Science and Technology and a fervent supporter of Phương. See http://www.nhantrachoc.net.vn/forum/showthread.php?t=2397 (accessed 16 March 2011). About the various preparatory steps for the research, see http://thegioivohinh. com/diendan/showthread.php? $\mathrm{t}=1584$. The project report has been circulated through various blogs and Internet forums concerned with spiritual matters. See, for example, http://thegioivohinh.com/diendan/showthread.php?t=1584 (accessed 16 March 2011). However, we are grateful to Ngô Kiều Oanh for bringing this report to our attention by providing us with a copy.

24. See, for example, the report by Bùi Duy Tâm (2010), who served as the dean of Hue Medical School prior to 1975. Thanks go to Tai Van Ta for pointing out this reference.

25. See, for example, http://www.thuvienphapluat.vn/?CT $=$ NW\&NID $=29587$.

26. In a rural commune in coastal Northern Vietnam, Schlecker (n.d.) found that in 2006-2007 villagers consulted the psychic Nguyễn Văn Liên increasingly for obliterated graves of deceased civilians and also turned to psychics who were clearly not certified by the state.

27. The director of CIHC spoke of 10 genuine psychics in an interview. 


\section{References}

Abrahams, Roger D. 1986. “Ordinary and Extraordinary Experience.” Pp. 45-72 in Turner and Bruner 1986.

Bauman, Richard, and Charles L. Briggs. 1990. "Poetics and Performance as Critical Perspectives on Language and Social Life." Annual Review of Anthropology 19: 59-88.

Bruner, Edward M. 1986. "Experience and Its Expressions." Pp. 3-32 in Turner and Bruner 1986.

Bubandt, Nils. 2009. "Interview with an Ancestor: Spirits as Informants and the Politics of Possession in North Maluku." Ethnography 10, no. 3: 291-316.

Bùi Duy Tâm. 2010. "Linh Hồn Và Cõi Âm" [Souls and the Yin World]. http://sachhiem.net/ TONGIAO/tgB/BuuDuyTam.php.

Đào Nguyên Lan. 2007. "Không được run tay, cùn bút trước thế lực xấu” [With an Unquivering Hand and a Sharp Pen against Bad Influences]. http://vietbao.vn/Phong-su/Khongduoc-run-tay-cun-but-truoc-the-luc-xau/30184365/263/.

de Tréglodé, Benôit. 2001. Héros et Révolution au Viêt Nam. Paris: L’Harmattan.

Derrida, Jacques. [1974] 1998. Of Grammatology. Baltimore, MD: Johns Hopkins University Press.

Endres, Kirsten W. 2002. "Beautiful Customs, Worthy Traditions: Changing State Discourse on the Role of Vietnamese Culture." Internationales Asienforum 33, no. 3-4: 303-322. 2008. "Engaging the Spirits of the Dead: Soul-Calling Rituals and the Performative Construction of Efficacy." Journal of the Royal Anthropological Institute 14, no. 4: 755-773. 2011. Performing the Divine: Mediums, Markets, and Modernity in Urban Vietnam. Copenhagen: NIAS Press.

Fjelstad, Karen, and Thi Hien Nguyen. 2006. Possessed by the Spirits: Mediumship in Contemporary Vietnamese Communities. Ithaca, NY: Cornell Southeast Asia Program Publications.

Gustafsson, Mai Lan. 2009. War and Shadows: The Haunting of Vietnam. Ithaca, NY: Cornell University Press.

James, William. [1907] 1981. Pragmatism. Indianapolis, IN: Hackett Publishing.

Jellema, Kate. 2005. "Making Good on Debt: The Remoralisation of Wealth in Post-Revolutionary Vietnam.” Asia Pacific Journal of Anthropology 6, no. 3: 231-248. 2007. "Everywhere Incense Burning: Remembering Ancestors in Đổi Mới Vietnam." Journal of Southeast Asian Studies 38 no. 3: 467-492.

Kapferer, Bruce. 1997. The Feast of the Sorcerer: Practices of Consciousness and Power. Chicago: University of Chicago Press.

Kleinen, John. 1999. Facing the Future, Reviving the Past: A Study of Social Change in a Northern Vietnamese Village. Singapore: Institute of Southeast Asian Studies.

Kwon, Heonik. 2006. After the Massacre: Commemoration and Consolation in Ha My and My Lai. Berkeley: University of California Press. 2008. Ghosts of War in Vietnam. Cambridge: Cambridge University Press.

Lewis, I. M. [1971] 1989. Ecstatic Religion: A Study of Shamanism and Spirit Possession. London and New York: Routledge.

Lienhardt, Godfrey. 1961. Divinity and Experience: The Religion of the Dinka. Oxford: Clarendon Press.

Lojkine, Boris, dir. 2005. Les âmes errantes. Les Films du Paradoxe (released as a DVD in 2007).

Luong, Hy Van. 1993. "Economic Reform and the Intensification of Rituals in Two North Vietnamese Villages, 1980-90.” Pp. 259-291 in The Challenge of Reform in Indochina, ed. B. Ljunggren. Cambridge, MA: Harvard University Press.

1994. "The Marxist State and the Dialogic Re-Structuration of Culture in Rural Vietnam." Pp. 79-114 in Indochina: Social and Cultural Change, ed. D. Elliott, H. V. Luong, B. Kiernan, and T. Mahoney. Monograph Series No. 7. Claremont, CA: Keck Center for International and Strategic Studies.

2007. "The Restructuring of Vietnamese Nationalism." Pacific Affairs 80, no. 3: 439-453. 
Malarney, Shaun K. 1996. “The Limits of 'State Functionalism' and the Reconstruction of Funerary Ritual in Contemporary Northern Vietnam." American Ethnologist 23: 540-560.

2001. “'The Fatherland Remembers Your Sacrifice': Commemorating War Dead in North Vietnam." Pp. 46-76 in The Country of Memory: Remaking the Past in Late Socialist Vietnam, ed. H.-T. Ho Tai. Berkeley: University of California Press.

2002. Culture, Ritual, and Revolution in Vietnam. New York: RoutledgeCurzon.

Marr, David G. 1981. Vietnamese Tradition on Trial, 1920-1945. Berkeley: University of California Press.

Mydans, Seth. 1999. "Of Soldiers Lost, but Not Forgotten, in Vietnam." New York Times, 19 April. http://www.mishalov.com/Vietnam_MIA.html.

Ngọc Huyền. 2006. “Người có hiện tượng lạ: Khoa học, không phải huyễn hoặc!” [People with Strange Phenomena: Science, Not Delusion!]. VietnamNet Online, 6 November. http://vietbao.vn/Khoa-hoc/Nguoi-co-hien-tuong-la-Khoa-hoc-khong-phai-huyenhoac/20630589/189/ (accessed 16 March 2011).

Nguyên Bảng. 2007. "Nhiều nhà ngoại cảm tìm mộ liệt sĩ được khen thưởng” [Psychics Who Found War Martyr Graves Receive Praise]. Tiền Phong Online, 23 July. http:// www.tienphong.vn/Tianyon/Index.aspx?ArticleID $=90529 \&$ ChannelID $=46$.

Nguyễn Chu Phác. 2000. "Ngày xuân nói chuyên làm phim 'tìm đồng đội' ở núi Non Nước" [Springtime Talk about Shooting the Film Finding Our Fellow Soldier at Non Nước Mountain]. An Ninh Thế Giói, no. 162, 27 January, 1, 14-15, 29.

Nguyễn Viêt Chiến. 1997. "Chung quanh những vụ tìm mộ liệt sĩ từ xa của nhà ngoại cảm Nguyễn Văn Liên: Một khả năng đặc biệt trong vòng nghiên cứu của khoa học” [The Grave Findings from Afar of Psychic Nguyễn Văn Liên: A Special Ability under the Scrutiny of Scientific Research]. Thanh Niên, no. 192, 1 December, 9.

Ninh, Kim Ngoc Bao. 2002. A World Transformed: The Politics of Culture in Revolutionary Vietnam, 1945-1965. Ann Arbor: University of Michigan Press.

Pelley, Patricia. 2002. Postcolonial Vietnam: New Histories of the National Past. Durham, NC: Duke University Press.

Pham Quynh Phuong. 2009. Hero and Deity: Tran Hung Dao and the Resurgence of Popular Religion in Vietnam. Chiang Mai: Mekong Press.

Phan, Chánh Công. 1993. "The Vietnamese Concept of the Human Souls and the Rituals of Birth and Death.” Southeast Asian Journal of Social Science 21, no. 2: 159-198.

Phua, Joe, dir. 2006. Psychic Vietnam. Infocus Asia for BBC’s This World.

Pomonti, Jean-Claude. 2000. "Le Vietnam et ses âmes mortes.” Le Monde, 2 May.

Rosaldo, Michelle Z. 1984. "Toward an Anthropology of Self and Feeling." Pp. 137-157 in Culture Theory: Essays on Mind, Self, and Emotion, ed. R. A. Shweder and R. A. LeVine. Cambridge: Cambridge University Press.

Schlecker, Markus. n.d. Bones and the Emergent Welfare State in Late Socialist Vietnam. Unpublished monograph.

Scott, James. 1998. Seeing Like a State: How Certain Schemes to Improve the Human Condition Have Failed. New Haven, CT: Yale University Press.

Sharp, Lesley A. 1993. The Possessed and the Dispossessed: Spirits, Identity, and Power in a Madagascar Migrant Town. Berkeley: University of California Press.

Stoller, Paul. 1995. Embodying Colonial Memories: Spirit Possession, Power, and the Hauka in West Africa. New York: Routledge.

Taylor, Philip. 2001. Fragments of the Present: Searching for Modernity in Vietnam's South. Honolulu: University of Hawai'i Press.

Thu Hằng. 2005. "Ngày Xuân, thử bàn về thế giới tâm linh!" [Springtime Discussion on the Spiritual World]. Hà Nội Mới Online, 7 February, http://www.hanoimoi.com.vn/newsdetail/ Cong_nghe/37090/ngay-xuan-th7917-ban-v7873-th7871-gi7899i-tam-linh!.htm.

Trần Ngọc Lân. 2007. Nhũng Chuyện về Thế Giới Tâm Linh [Stories about the Spiritual World]. Hanoi: Culture and Information Publishing House.

Trường Chinh. 1977. Selected Writings. Hanoi: Foreign Languages Publication House. 
Tùng Đệ. 1997. “Trăm nghe không băng một thấy về 'Nhà Ngoại Cảm’ Nguyễn Văn Liên” [A Thousand Hearsays Do Not Equal One Glimpse: On the 'Psychic' Nguyễn Văn Liên]. Báo Tiền Phong, 9 December, 4.

Turner, Victor W. [1982] 1996. From Ritual to Theatre: The Human Seriousness of Play. New York: PAJ Publications.

1986. "Dewey, Dilthey and Drama: An Essay in the Anthropology of Experience." Pp. 33-44 in Turner and Bruner 1986.

Turner, Victor W., and Edward M. Bruner, eds. 1986. The Anthropology of Experience. Urbana: University of Illinois Press.

UIA (Union for Applied Informatics). n.d. Nói Chuyện Vói Ngưòi âm (Tài Liệu Tham Khảo) [Speaking with the Dead (Consultation Documentation)]. Hanoi.

Woodside, Alexander. 1976. Community and Revolution in Modern Vietnam. Boston, MA: Houghton Mifflin.

1997. "The Struggle to Rethink the Vietnamese State in the Era of Market Economics." Pp. 61-77 in Culture and Economy: The Shaping of Capitalism in Eastern Asia, ed. T. Brook and H. V. Luong. Ann Arbor: University of Michigan Press.

Xuân Nguyên. 1997. "Quản lý hoạt động của các 'Nhà Ngoại Cảm”” [Managing the Activities of 'Psychics']. Lao Động Xã Hội, 3 August, 1. 